\title{
The labral gland in termite soldiers
}

\section{VALERIA PALMA-ONETTO ${ }^{1,2}$, KRISTÝNA HOŠKOVÁ $^{3}$, BARBORA KŘÍŽKOVÁ ${ }^{1}$ ROMANA KREJČÍŘOVÁ ${ }^{3}$, JITKA PFLEGEROVÁ4, FILIPA BUBENÍČKOVÁ RUDY PLARRE ${ }^{5}$, CECILIA A. L. DAHLSJÖÖ,6, JIŘÍ SYNEK ${ }^{1}$, THOMAS BOURGUIGNON ${ }^{1,7}$, DAVID SILLAM-DUSSÈS ${ }^{2,8 \dagger}$ and JAN ŠOBOTNÍK ${ }^{1 * \dagger}$}

\author{
${ }^{1}$ Faculty of Forestry and Wood Sciences, Czech University of Life Sciences, Prague, Czech Republic \\ ${ }^{2}$ University Paris 13 - Sorbonne Paris Cité, Laboratory of Experimental and Comparative Ethology, \\ Villetaneuse, France \\ ${ }^{3}$ Faculty of Agrobiology, Food and Natural Resources, Czech University of Life Sciences, Prague, Czech \\ Republic \\ ${ }^{4}$ Institute of Entomology, Biology Centre, Academy of Sciences of the Czech Republic, České Budějovice, \\ Czech Republic \\ ${ }^{5}$ Bundesanstalt für Materialforschung und -prüfung, Berlin, Germany \\ ${ }^{6}$ Environmental Change Institute, University of Oxford, South Parks Road, Oxford OX1 3QY, UK \\ ${ }^{7}$ Okinawa Institute of Science \& Technology Graduate University, 1919-1 Tancha, Onna-son, Okinawa \\ 904-0495, Japan \\ ${ }^{8}$ Institute of Research for Development - Sorbonne Universités, Institute of Ecology and Environmental \\ Sciences of Paris, Bondy, France
}

Received 6 November 2017; revised 28 November 2017; accepted for publication 28 November 2017

\begin{abstract}
The evolutionary success of termites has been driven largely by a complex communication system operated by a rich set of exocrine glands. As many as 20 different exocrine organs are known in termites. While some of these organs are relatively well known, only anecdotal observations exist for others. One of the exocrine organs that has received negligible attention so far is the labral gland. In this study, we examined the structure and ultrastructure of the labrum in soldiers of 28 termite species. We confirm that the labral gland is present in all termite species, and comprises two secretory regions located on the ventral side of the labrum and the dorso-apical part of the hypopharynx. The labrum of Neoisoptera has a hyaline tip, which was secondarily lost in Nasutitermitinae, Microcerotermes and species with snapping soldiers. The epithelium of the gland generally consists of class 1 secretory cells, with an addition of class 3 secretory cells in some species. A common feature of the secretory cells is the abundance of smooth endoplasmic reticulum, an organelle known to produce lipidic and often volatile secretions. Our observations suggest that the labral gland is involved in communication rather than defence as previously suggested. Our study is the first to provide a comprehensive picture of the structure of the labral gland in soldiers across all termite taxa.
\end{abstract}

ADDITIONAL KEYWORDS: exocrine gland - hypopharynx - labrum - Termitoidae - ultrastructure - Isoptera.

\section{INTRODUCTION}

Termites are an important food resource for a range of animals (Redford \& Dorea, 1984), and they compete for resources with other wood- and soil-feeding taxa (Šobotník, Jirosová \& Hanus, 2010a). Termites protect themselves through passive and active

*Corresponding author. E-mail: sobotnik@fld.czu.cz

These authors contributed equally to the study. defence mechanisms, including a cryptic lifestyle, the construction of defensive structures (Korb, 2011) and investments into a caste of defenders: the soldiers (Haverty, 1977). While the primary weapon of termite soldiers is generally their powerful mandibles, glands that produce defensive compounds are of comparable importance (Prestwich, 1984; Šobotník et al., 2010a).

Termites use intricate communication systems, the complexity of which is reflected in the development of 20 different signal-producing exocrine organs (Billen \& 
Šobotník, 2015). Four glands are found in most termite species: the frontal gland, the sternal gland, the labial glands and the mandibular glands. The presence of other exocrine organs is restricted to specific termite lineages, or to certain castes. The function of these lineage-/caste-specific glands is not fully understood, apart from the defensive function of the crystal glands in Neocapritermes taracua workers (Šobotník et al., 2012, 2014; Bourguignon et al., 2016). The labral gland is one of these poorly known exocrine glands, known only from the soldier caste of three termite species (Deligne, Quennedey \& Blum, 1981; Quennedey, 1984; Šobotník et al., 2010b; Costa-Leonardo \& Haifig, 2014), and from some imagoes (Křížková et al., 2014).

The labral gland was first described on the ventral side of the labrum in Macrotermes bellicosus (Deligne et al., 1981) and was later found also on the dorsal side of the hypopharynx in other Macrotermitinae species (Quennedey, 1984). The presence of labral glands in other taxa is thought to be indicated by a hyaline tip, located on the tip of the labrum (Deligne et al., 1981). The labral gland of $M$. bellicosus is composed of class 1 secretory cells only (according to the classification of Noirot \& Quennedey, 1974), while additional class 3 secretory cells have been found in the labral glands of Glossotermes oculatus and Cornitermes cumulans soldiers (Šobotník et al., 2010b; Costa-Leonardo \& Haifig, 2014). The function of the labral gland has not been studied for any termite species, and the literature suggests that it produces toxic secretions that impregnate the mandibular edges (Deligne et al., 1981; Quennedey, 1984). In this paper, we provide the first comprehensive description of the structure of the labral gland in the soldiers of 28 species, representatives of the termite tree of life.

\section{MATERIAL AND METHODS}

\section{DIRECT OBSERVATIONS}

Living termites were observed and photographed using Canon EOS 6D and Canon EOS 5D SR cameras, combined with Canon EF $100 \mathrm{~mm}$ f/2.8L Macro IS USM and Canon MP-E $65 \mathrm{~mm}$ f/2.8 lenses, and equipped with the Canon Macro Twin Lite MT-24EX flash. The photographs were used to compare the shape of the labrum and the presence of a hyaline tip in termite soldiers.

\section{OPTICAL MICROSCOPY AND TRANSMISSION ELECTRON MICROSCOPY}

Soldier labral glands were studied using three different fixatives: fixative with phosphate buffer $(0.2 \mathrm{M}$, pH 7.2 buffer/formaldehyde 10\%/glutaraldehyde $8 \%=2: 1: 1$ ), cacodylate buffer $(0.2 \mathrm{M}, \mathrm{pH} 7.3$ buffer/glutaraldehyde $8 \%$ / distilled water $=2: 1: 1$ ) and standard Bouin's solution (for details see Supplementary Information, Table S1). For electron microscopy, soldier heads were cut off and the mandibles were removed to facilitate sectioning. The mandibles were left intact in the minor soldiers of Rhinotermitinae and in all Nasutitermitinae. Samples were postfixed using $2 \%$ osmium tetroxide, and embedded in Spurr resin. The samples were cut into $0.5-\mu \mathrm{m}$ sections using a Reichert Ultracut ultramicrotome and stained with Azure II for analysis with optical microscopy.

\section{HISTOLOGY}

The samples were dehydrated using a ethanol series, transferred to xylene and embedded in paraffin. Polymerization was carried out in an oven at $56-58{ }^{\circ} \mathrm{C}$ for $2 \mathrm{~h}$. The samples were cut into sections 5-10 $\mu \mathrm{m}$ thick using Bamed pfm Rotary 3004 M microtome, placed on a slide coated with eggwhite/glycerol, stained with Mallory's trichrome stain and then made clear with xylen. For additional details see Table S1.

\section{ELECTRON MICROSCOPY}

We dissected the heads of freshly freeze-killed soldiers, and removed the mandibles, maxillae and labium. The heads were thereafter dehydrated using an acetone series. The samples were dried using the critical-point method and glued onto an aluminium holder using thermoplastic adhesive. The samples were then sputter-coated with gold and observed using a Jeol $6380 \mathrm{LV}$ scanning electron microscope. The mouthparts of three species (Embiratermes neotenicus, Coptotermes formosanus and Sphaerotermes sphaerothorax) were cleaned via argon plasma etching in a sputter coater machine (Bal-Tec SCD 050).

Ultrastructural features were studied in selected samples (see Table S1) using a Jeol 1011 transmission electron microscope, as described by Šobotník, Weyda \& Hanus (2003).

\section{EVOLUTION OF THE HYALINE TIP}

We reconstructed the presence of the hyaline tip using previously published phylogenetic trees (Bourguignon et al., 2015, 2017). We carried ancestral state reconstruction with Mesquite (Maddison \& Maddison, 2010), on the presence/absence of the hyaline tip, using the Mk1 likelihood model and parsimony analyses.

\section{RESULTS}

The labral gland is a constituent part of the labrum (Fig. 1A, B). The labrum is dorsally sclerotized, and membranous on the ventral side, with lower sclerotization towards the tip, often with a transparent 

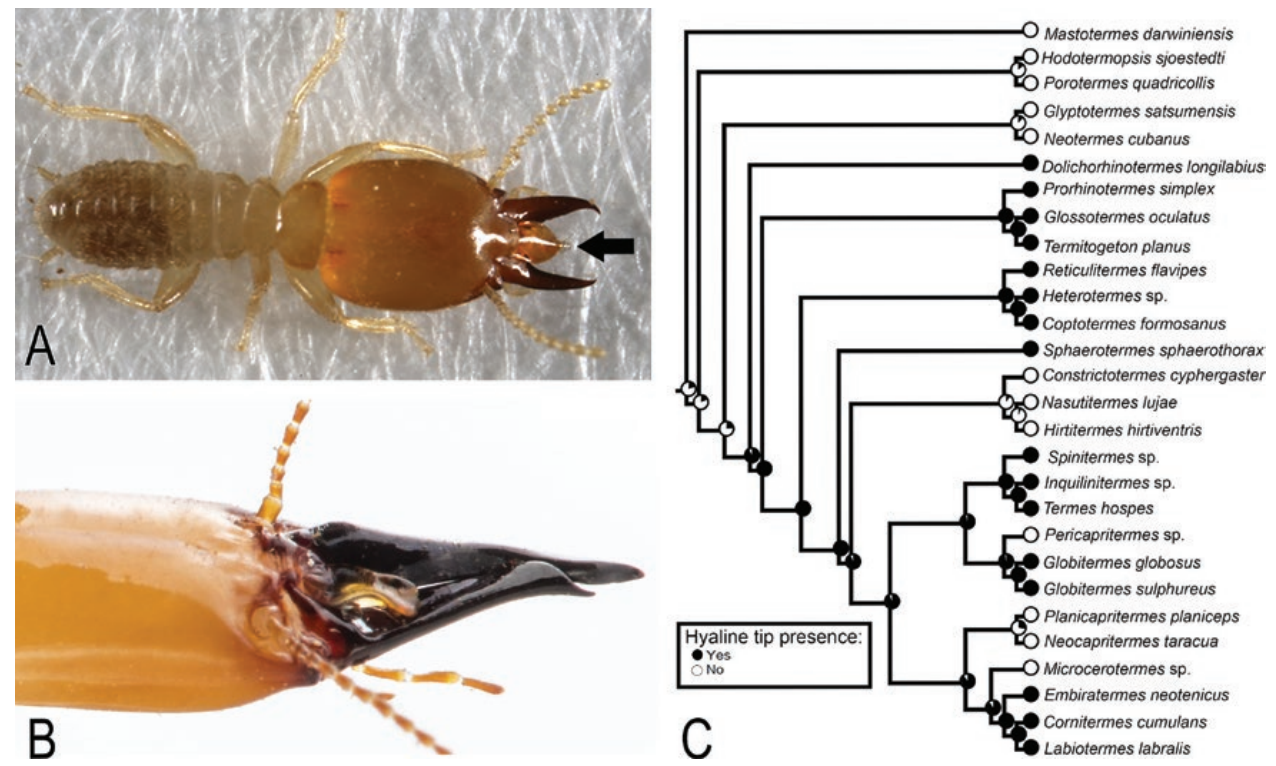

Figure 1. (A) Sphaerotermes sphaerothorax soldier. Arrow marks the hyaline tip of the labrum. (B) Head of Neocapritermes taracua soldier. (C) Phylogenetic tree showing the evolution of the hyaline tip in soldier caste termites. The presence or absence of the hyaline tip is marked by black or white circles, respectively.

inflated apical part termed the 'hyaline tip'. The hyaline tip appears as a transparent extensible protrusion of the labrum occurring in many taxa of Rhinotermitidae and Termitidae (Fig. 1C). The presence of the hyaline tip is variable, depending on species. The hyaline tip has been lost in several lineages, including the snapping soldiers and all Nasutitermitinae (Figs 1C, S1).

\section{SCANNING ELECTRON MICROSCOPY}

The ventral facies of the labrum were flexible and appeared wrinkled (Fig. 2A), while the dorsal facies were more rigid with a sclerotized cuticle. The ventral side of the labrum generally carried a few tens of sensillae (Fig. 2B), probably acting as contact chemoreceptors [based on combined scanning (SEM) and transmission electron microscopy (TEM) evidence, see below], with possible mechanosensitive function (based on striking similarity to campaniform sensillae). While the dorsal side of the labrum was usually smooth, the ventral facies of the labrum usually showed borders between the underlying epidermal cells, which appeared as irregular angular structures between 4 and $6 \mu \mathrm{m}$ in the largest dimension. These borders were well delimited in certain parts of the ventral surface of the labrum, often appearing as ridges or spines extending beyond the cell border. These features were especially developed in Neotermes cubanus, Glossotermes oculatus, Neocapritermes taracua, Spinitermes sp. and Labiotermes labralis. The same pattern was also observed along the midline of the labrum in Prorhinotermes simplex, the basal half of the labrum in Coptotermes formosanus (Fig. 2A, B) and Sphaerotermes sphaerothorax, and the basal part of the labrum in Embiratermes neotenicus. In all specimens, the apical and ventro-lateral part of the labrum possessed numerous pores typically about $30-50 \mathrm{~nm}$ in diameter (Fig. 2C).

\section{OPTICAL MICROSCOPY}

The labral gland appeared as a thickened epithelium located on the ventral side of the labrum, with possible extension to the dorsal side at the labrum apex. An independent portion of secretory epithelium appeared also on the dorso-apical part of the hypopharynx (Fig. 3A, B). Labral gland secretions were shown to accumulate in the space between the secretory epithelium and the overlaying cuticle with no reservoir.

The labral gland secretory epithelium varied in thickness among species, most commonly ranging between 20 and $30 \mu \mathrm{m}$. The thinnest epithelium was found in Nasutitermes lujae $(2 \mu \mathrm{m})$ and the thickest epithelium was found in the large soldiers of Psammotermes hybostoma (147 $\mu \mathrm{m})$ (Table S1). Hypopharyngeal thickness varied between 4 and $30 \mu \mathrm{m}$. The ultrastructural features were nearly identical between the labral and hypopharyngeal regions of the labral gland in all species. The shape and overall size of the labral gland were diverse and not proportional to the size of the labrum. While some labral glands covered the entire labrum, others covered less than half of the labral ventral area. 

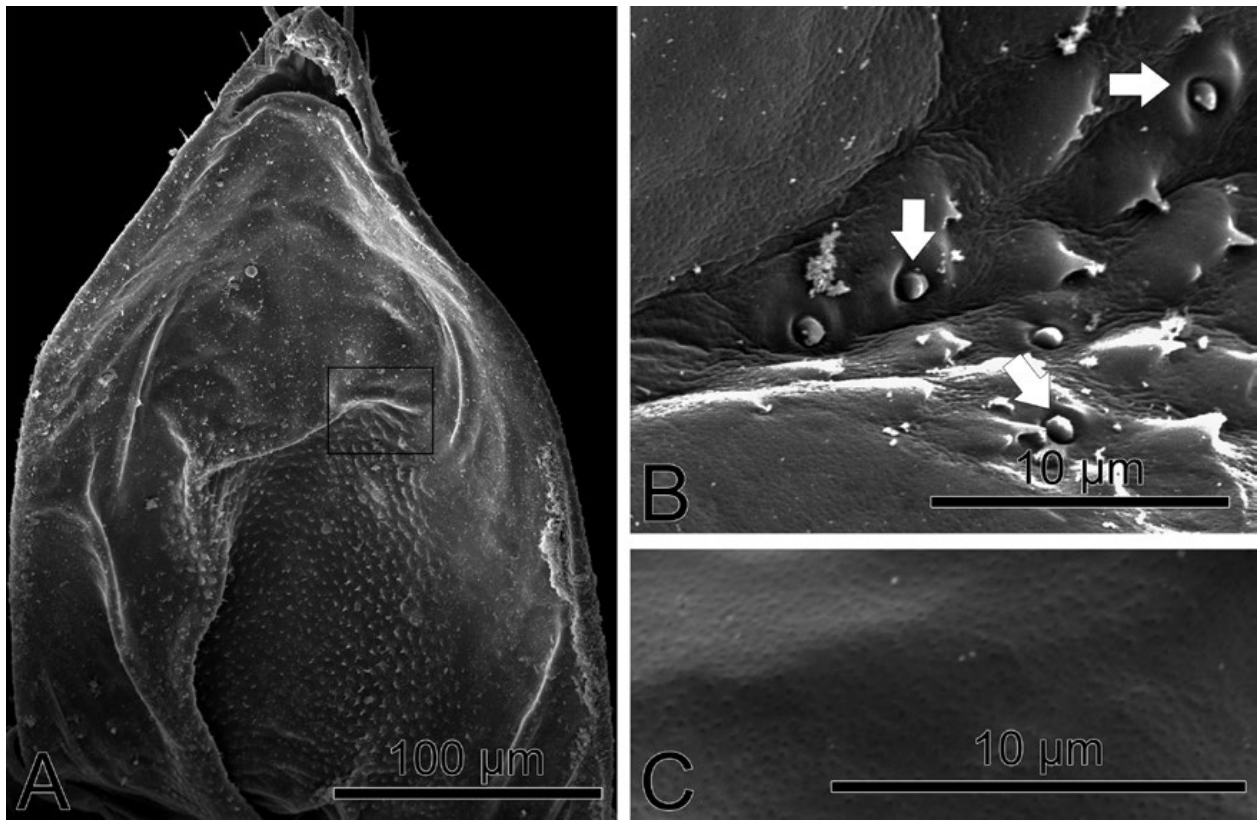

Figure 2. Labral gland development. (A) Micrograph of the ventral side of the labrum of Coptotermes formosanus; the small rectangle indicates the sector where the micrograph in B was taken. (B) Region with a group of sensillae (marked with white arrows) in C. formosanus labrum. (C) High-magnification micrograph of the apical region with epicuticular pores in Sphaerotermes sphaerothorax labrum.

Within the four studied species with soldier subcastes, the thickness of the labral gland increased with the size of the soldier morph (Table S1).

\section{TRANSMISSION ELECTRON MICROSCOPY}

TEM revealed that the labral and hypopharyngeal epithelium were made up of secretory cells. The ultrastructural features of the secretory cells in the labral and hypopharyngeal regions of the labral gland were almost identical, and are thus described together.

The labral gland was predominantly made up of columnar class 1 secretory cells (according to the classification of Noirot \& Quennedey, 1974) that were characterized by an abundance of smooth endoplasmic reticulum (ER), vesicles of different electron densities, abundant mitochondria, numerous microtubules orientated apico-basally, glycogen granules, myelin figures and sparse rough ER mainly located around the nucleus (Fig. 4A-C). The secretory cells could easily be differentiated from the non-modified cells (Fig. S3A) as the latter are thinner and lack the characteristics mentioned above. Electron-lucent vesicles were also relatively common within the cells, although they were rarely observed to be released (then including the membrane) at the cell apex, while electron-dense granules were rare. The secretory cell cytoplasm often contained lipid-like droplets (around 1-2 $\mu \mathrm{m}$ in diameter; Fig. S3B, C) that were located freely in the cytoplasm and particularly abundant in major soldiers of Dolichorhinotermes longilabius. The droplets in D. longilabius had a foamy appearance and turned into lucent vesicles that were occasionally excreted at the secretory cell apex. Junctions between neighbouring class 1 cells were formed by apical zonulae adherens followed by septate junctions, while the basal parts of the membranes were devoid of any junctions. Basal invaginations were well developed throughout the gland, and on average were about $5 \mu \mathrm{m}$ deep (up to $20 \mu \mathrm{m}$ in Labiotermes labralis) (Fig. 4A) and showed frequent pinocytotic activity (Fig. S3D). The nucleus of the class 1 cells was basally located and elliptic or slightly irregular in shape. The largest dimension of the nucleus was $5 \mu \mathrm{m}$ (rarely up to $10 \mu \mathrm{m}$ ) and the nucleus was predominantly filled with dispersed chromatin with few aggregates. Microvilli were well developed, about $1.5 \mu \mathrm{m}$ in length (rarely up to 3-4 $\mu \mathrm{m}$ ), approximately $100 \mathrm{~nm}$ thick, and always had a central channel about $40 \mathrm{~nm}$ in diameter (Figs 4A, S3C, E). The basal invaginations and microvilli of the hypopharyngeal region of the labral gland were always shorter than those of the labral region. Microvilli were in some cases longer in the central part of the gland than in the gland margins.

The cuticle was in general made up of three layers, the endocuticle of helicoid structure, exocuticle showing no discernible layers and a thin epicuticle (see Table S1). The labral gland secretions were stored in the space between 

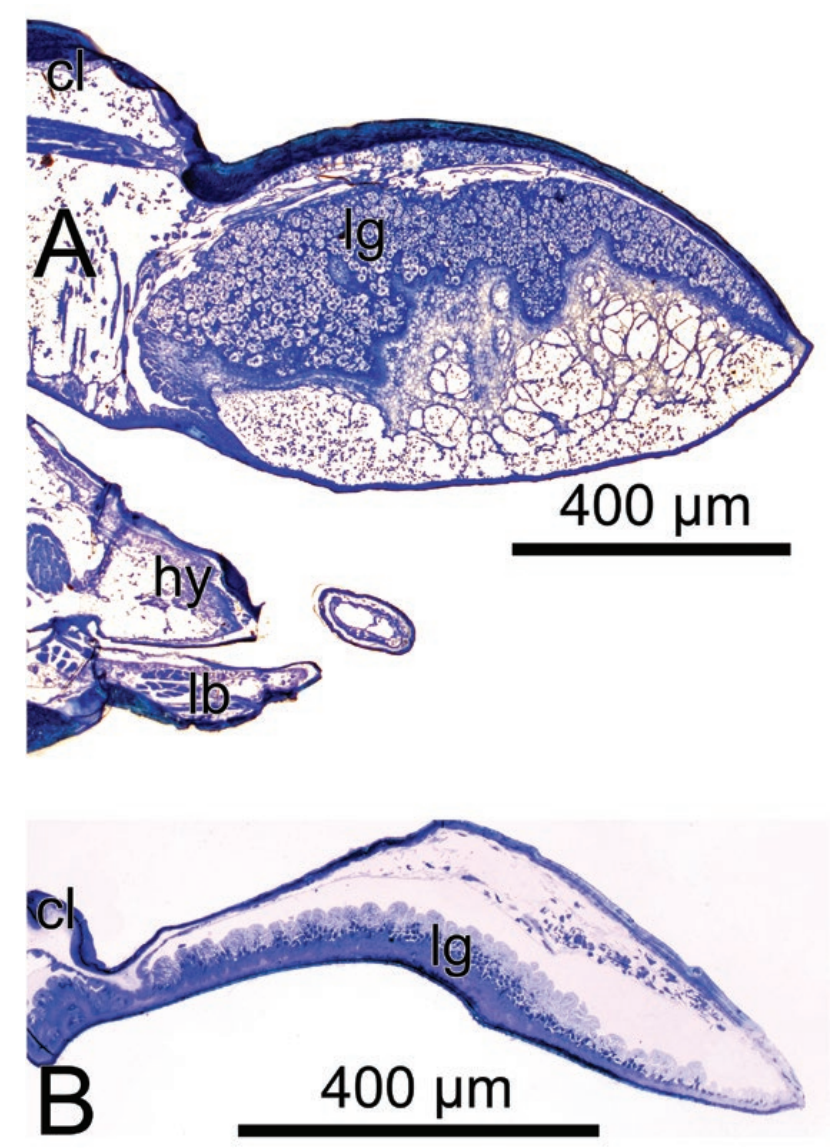

Figure 3. Sagittal sections of the forehead of Psammotermes hybostoma medium soldier (A) and Neocapritermes taracua soldier (B), showing the secretory epithelium in hypopharynx. Abbreviations: cl, clypeus; hy, hypopharynx; lb, labium; lg, labral gland.

the secretory epithelium, the overlying cuticle and inside the porous cuticle. There was no invaginated reservoir in any of the studied species. The cuticle showed numerous adaptations for release of the secretion, and these were more pronounced towards the labral tip (Fig. 2C, 4D, S4A, B). The cuticular modifications included an increase in the number and width of the pore canals, which widened towards the cuticle base (Fig. 4D), and the occurrence of epicuticular pores allowing for the secretion to be evacuated from the body.

Secretory cells were innervated by free axons frequently observed at the base of the secretory epithelium (Fig. 4C). The singular axons without envelope cells often occurred among the basal invaginations, and sometimes contained typical electron-dense grains of neurosecretions. A different kind of neural tissue was represented by groups of sensillae located along the central line of the labrum, each comprising between two and five sensory neurons (represented by distal dendrites) and corresponding envelope cells (Figs 4D, S4C).
Apart from the common organelles, large microtubule bundles running through secretory cells were found in Mastotermes darwiniensis, Hodotermopsis sjoestedti and Embiratermes neotenicus (Fig. S3D). Additionally, tracheae going through class 1 cells were found in $M$. darwiniensis and $H$. sjoestedti (Fig. S3E). Major soldiers of Dolichorhinotermes longilabius possessed particularly large amounts of lipid droplets, with electron-dense granules that dissolved into lucent vesicles. In all studied Nasutitermitinae the labral gland was relatively underdeveloped, although the cells retained the general characteristics of the labral gland.

Class 3 secretory cells, when present, commonly occurred on the dorsal side of the labrum and were generally separated from the secretory epithelium by non-modified epidermal cells. However, the class 3 cells were in few cases mixed with class 1 cells (Fig. 4E) in Glossotermes oculatus, Termes hospes, and in the minor soldiers ofDolichorhinotermes longilabius. In Mastotermes darwiniensis, by contrast, the class 3 secretory cells were located adjacent to the class 1 secretory cells. 

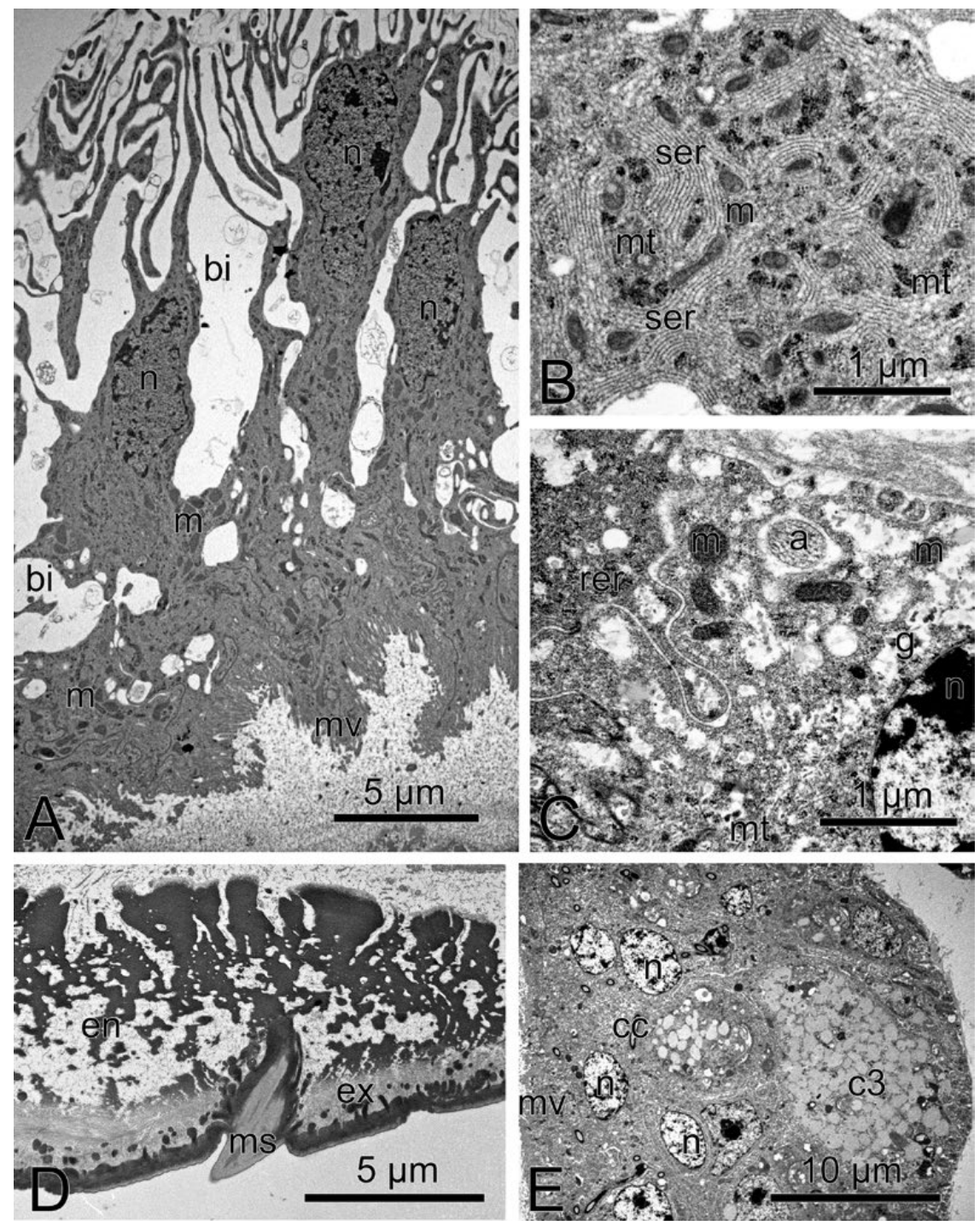

Figure 4. Ultrastructure of the labral gland in soldiers. (A) Overall development of the labral gland in Labiotermes labralis. Note the development of the apical microvilli and basal invaginations. (B) Detail of labral gland secretory cell class 1 cytoplasm in Neocapritermes taracua showing well-developed smooth endoplasmic reticulum. (C) Detail of labral gland secretory cell class 1 cytoplasm in large soldier of Dolichorhinotermes longilabius showing a free axon located at the base of the secretory epithelium. (D) Highly modified cuticle underlying the labral gland in Embiratermes neotenicus. Note enlarged pore canals ensuring secretion release and the margin of the sensillum. (E) Class 3 secretory cell in Glossotermes oculatus. Abbreviations: a, axon; c3, class 3 secretory cell; cc, conducting canal; en, endocuticle; ex, exocuticle; g, glycogen; bi, basal invaginations; m, mitochondria; ms, margin of the sensillum; mt, microtubule; mv, microvilli; n, nucleus; rer, rough endoplasmic reticulum; ser, smooth endoplasmic reticulum.

Class 3 cells did not touch either the apex or the basement membrane of the gland. Their cytoplasm predominantly contained vesicles of moderate electron density (Fig. 4E), but also contained rough ER and free ribosomes, Golgi apparatus, mitochondria, microtubules and rare electron-dense granules. The cells were equipped with porous receiving canals continuous with a conducting canal approximately $0.4 \mu \mathrm{m}$ in diameter. The conducting canal comprised inner (approximately $40 \mathrm{~nm}$ thick) and outer (approximately $6 \mathrm{~nm}$ thick) epicuticles (Fig. 4E).

\section{DISCUSSION}

The labral gland is an integral part of the labrum, which is a thin lip-like structure that covers the dorsal side of the pre-oral cavity. The labral gland 
belongs to the basic body plan of termites. However, its presence has rarely been investigated. Here we report on its presence and cytological features in soldiers of 28 species across the termite phylogeny. The presence of the labral gland in all observed species was unexpected as the gland has only been reported in soldiers of three termite species previously (Deligne et al., 1981; Quennedey, 1984; Šobotník et al., 2010b; Costa-Leonardo \& Haifig, 2014). The labral gland was originally recognized as an exocrine organ by Deligne et al. (1981). Quennedey (1984) described the hypopharyngeal part of the labral gland and suggested that the occurrence of the hyaline tip proves the presence of the labral gland in termite soldiers. It was only recently, and following Šobotník et al.'s (2010b) study on the defensive glands in Glossotermes oculatus, and Costa-Leonardo \& Haifig's (2014) study on the labral gland in Cornitermes cumulans, that additional data on the labral gland appeared. In addition to the presence of the labral gland in termite soldiers, it was also recently observed in some imagoes (Kř́žková et al., 2014) and certain workers (Palma-Onetto V and Šobotník J, our unpublished data). These random observations suggest that the labral gland might be present in all termite castes, pointing to its importance during termite evolution.

The labral gland is split into two secretory regions located in the ventral part of the labrum and dorsoapical part of hypopharynx, respectively. Although the secretory epithelium is always thicker in the labral part, the ultrastructure of secretory cells present in these two secretory regions is virtually identical. We therefore expect that both secretory regions play the same role, and should thus be treated as a single gland. The nomenclatural change from 'labral gland' to 'cibarial gland' proposed by Quennedey (1984), based on gland development in two regions, is therefore redundant and the original name, well accepted by the scientific community, should prevail.

The hyaline tip is a traditionally described morphological character. The dorsal side of the labrum is always sclerotized, while the ventral part is always formed by a lucent membranous cuticle. However, species may differ in the level of sclerotization of the dorsal side, especially at the labrum apex. While some soldiers show an unchanged level of labrum sclerotization (hyaline tip absent), the level of sclerotization often decreases towards the labrum apex in others (hyaline tip present). All basal taxa primarily lack the hyaline tip, which evolved in a common ancestor of Rhinotermitidae and Termitidae, and was subsequently lost at least four times independently: once in Nasutitermitinae, in which the entire labrum is greatly reduced in size, twice independently in lineages with snapping soldiers, Pericapritermes and Neocapritermes + Planicapritermes, and once in Microcerotermes. While the hyaline tip has been shown to disappear in some lineages, the labral gland was found in all termite families studied here. This suggests that the evolution of snapping mandibles did not see a loss of the labral gland and that the evolution of mandibles has not necessarily been accompanied by a reduction or loss of chemical adaptation (Kyjaková et al. 2015).

The cytological features of the labral gland showed many similarities among all studied species. Additionally, the four species with polymorphic soldiers that we studied showed that the labral gland volume increased with sub-caste size and was particularly pronounced in Psammotermes hybostoma.

The common features shared by labral and hypopharyngeal parts of the labral glands include: (1) abundance of smooth ER, (2) the presence of apical microvilli with a central channel, (3) welldeveloped basal invaginations ensuring the intake of precursors from the haemolymph, and (4) cuticular modifications in the tip of the labral gland allowing gland secretions to reach the exterior (see also Deligne et al., 1981; Quennedey, 1984; Šobotník et al., 2010b; Costa-Leonardo \& Haifig, 2014). These ultrastructural features are a conservative account of the characteristics of the two secretory regions in the studied species, which suggest that the labral gland has the same function among all species. The labral gland secretion is stored between the secretory epithelium and the overlying cuticle, as well as within the cuticle itself. Labral secretions from the glandular cells are under neural control, supposedly from the brain, as singular axons have often been detected at the base of the secretory epithelium.

The function of the labral gland is probably not defensive due to the absence of a reservoir, a feature characteristic of defensive glands (Chapman, 2013). Additionally, the labral gland is present in soldiers of all species, irrespective of their defensive strategies, including species having soldiers with nasus glands, with snapping mandibles or performing body rupture. The composition of the labral gland secretion remains unknown despite our repeated attempts to identify labral gland-specific compounds. This may be due to the small size of the labral gland and the unknown nature of its secretion. Nevertheless, the high abundance of a smooth ER suggests that the secretion may have a lipidic and volatile nature and could be used in communication (Percy-Cunningham \& MacDonald, 1987; Nakajima, 1997; Tillman et al., 1999; Alberts et al., 2002).

The presence of specialized receptors on the ventral side of the labrum is likely to aid in dosage of labral secretions. As all observed receptors contained several 
dendrites, a chemosensory function is likely for all species while a mechanoreceptive function remains hypothetical. The idea that the labral receptors respond to mechanical pressure has a functional parallel in the sternal gland, secretion releases from which are controlled by groups of campaniform sensillae (Stuart \& Satir, 1968; Quennedey et al., 2008).

Class 3 cells occur frequently on the dorsal side of the labrum and on the sclerotized body cuticle (Šobotník et al., 2004; Šobotník, Weyda \& Hanus, 2005). Class 3 cells may also occur adjacent to the labral gland secretory epithelium but should not be considered as part of the labral gland until the two cell classes are combined, as seen in G. oculatus (Šobotník et al., $2010 \mathrm{~b}$ ), the minor soldiers of $D$. longilabius (presented here), C. cumulans (Costa-Leonardo \& Haifig, 2014) and T. hospes (presented here). Class 3 cells have not been observed in the hypopharyngeal part of the labral gland in any of above-mentioned species. The ultrastructure of the class 3 secretory cells is uniform in termites, irrespective of their caste (Costa-Leonardo \& Shields, 1990; Šobotník et al., 2004) and position in the gland, such as mandibular (Lambinet, 1959; Cassier, Fain-Maurel \& Lebrun, 1977), sternal (Noirot \& Quennedey, 1974; Quennedey et al., 2008), tergal (Ampion \& Quennedey, 1981; Šobotník et al., 2005) and epidermal (Šobotník et al., 2003). The secretory cells are always rich in rough ER and Golgi apparatus, and contain variable amounts of moderately electronlucent vesicles released to the extracellular reservoir ('end apparatus'), into which the cuticular canal is inserted. This ultrastructure suggests that rough ER produces proteinaceous water-soluble secretions that are configured in the Golgi apparatus (Hand \& Oliver, 1984) before being released on the surface of the body cuticle. These secretions may appear as the uppermost layer of the epicuticles protecting the lower layers from abrasion (Chapman, 2013).

\section{CONCLUSION AND FURTHER HYPOTHESES}

The labral gland has previously been suggested to be a synapomorphy of Neoisoptera (Šobotník et al., 2010a). The presence of the labral gland in termite soldiers of all studied species suggests that the labral gland evolved with the soldier caste where it has remained an important organ. Moreover, the labral gland has long been thought to primarily have a defensive function. Gland secretion was thought to be on the mandibles and deposited into the wound following bite (Deligne et al., 1981; Quennedey, 1984; Šobotník et al., 2010b; Costa-Leonardo \& Haifig, 2014). However, preliminary observations based on the morphology, structure and ultrastructure of the labral gland suggest that labral gland secretion has a communicative function.

The presence of a labral gland in soldiers of all termite species suggests that it has a fundamental role in colony survival and success. Our data suggest that the function of the labral gland may be related to communication. This hypothesis is supported by personal observations of soldiers wiping their labrum against the floor after encountering an enemy. A better understanding of the function of the labral gland in termites is called for to enhance knowledge of termite defence mechanisms and communication behaviour.

\section{ACKNOWLEDGEMENTS}

Credit for Figure 1B goes to Aleš Buček (OIST, Japan). We thank Mirek Hyliš from the Laboratory of Electron Microscopy (Faculty of Sciences, Charles University in Prague) for his help and support with SEM and TEM. We are grateful to Yves Roisin for constructive criticism of the manuscript. We also thank three anonymous reviewers for their helpful comments and suggestions. Financial support was provided by the project IGA FLD No. A13/17 (Czech University of Life Sciences, Prague).

\section{REFERENCES}

Alberts B, Johnson A, Lewis J, Raff M, Roberts K, and Walter P. 2002. Molecular Biology of the cell: the endoplasmic reticulum, 4th edn. New York: Garland Science.

Ampion M, Quennedey A. 1981. The abdominal epidermal glands of termites and their phylogenetic significance. In Howse PE, Clément JL, eds. Biosystematics of social insects. London: Academic Press, 249-261.

Billen J, Šobotník J. 2015. Insect exocrine glands. Arthropod Structure \& Development 44: 399-400.

Bourguignon T, Lo N, Cameron SL, Šobotník J, Hayashi Y, Shigenobu S, Watanabe D, Roisin Y, Miura T, Evans TA. 2015. The evolutionary history of termites as inferred from 66 mitochondrial genomes. Molecular Biology and Evolution 32: 406-421.

Bourguignon T, Šobotník J, Brabcová J, Sillam-Dussès D, Buček A, Krasulová J, Vytisková B, Demianová Z, Mareš M, Roisin Y, Vogel H. 2016. Molecular mechanism of the two-component suicidal weapon of Neocapritermes taracua old workers. Molecular Biology and Evolution 33: 809-819.

Bourguignon T, Lo N, Šobotník J, Ho SY, Iqbal N, Coissac E, Lee M, Jendryka MIM, Sillam-Dussès D, Krížková B, Roisin Y, Evans TA. 2017. Mitochondrial phylogenomics resolves the global spread of higher termites, ecosystem engineers of the tropics. Molecular Biology and Evolution 34: 589-597. 
Cassier P, Fain-Maurel MA, Lebrun D. 1977. Electron microscopic study of the mandibular glands of Kalotermes flavicollis fabr. (Isoptera; Calotermitidae). Cell and Tissue Research 182: 327-339.

Chapman RF. 2013. The insects: structure and function, 5 th edn. In Simpson SJ, Douglas AE, eds. The integument, gas exchange and homeostasis. Cambridge: Cambridge University Press, 464-496.

Costa-Leonardo AM, Shields KS. 1990. Morphology of the mandibular glands in workers of Constrictotermes cyphergaster (Silvestri) (Isoptera: Termitidae). International Journal of Insect Morphology and Embryology 19: 61-64.

Costa-Leonardo AM, Haifig I. 2014. Termite communication during different behavioral activities. In Witzani G, ed. Biocommunication of animals. Dordrecht: Springer, 161-190.

Deligne J, Quennedey A, Blum MS. 1981. The enemies and defense mechanisms of termites. In Hermann HR, ed. Social insects, Vol. 2. New York: Academic Press, 1-76.

Hand AR, Oliver C. 1984. The role of GERL in the secretory process. In Cantin M, ed. Cell biology of the secretory process. Basel: Karger Publishers, 148-170.

Haverty MI. 1977 The proportion of soldiers in termite colonies: a list and a bibliography. Sociobiology 2: 199-216.

Kyjaková P, Dolejšová K, Krasulová J, Bednárová L, Hadravová R, Pohl R, Hanus R. 2015 The evolution of symmetrical snapping in termite soldiers need not lead to reduced chemical defence. Biological Journal of the Linnean Society 115: 818-825.

Korb J. 2011. Termite mound architecture, from function to construction. In Bignell ED, Roisin Y, Lo N, eds. Biology of termites: a modern synthesis. Dordrecht: Springer, 349-373.

Křížková B, Bourguignon T, Vytisková B, Šobotník J. 2014. The clypeal gland: a new exocrine gland in termite imagoes (Isoptera: Serritermitidae, Rhinotermitidae, Termitidae). Arthropod Structure \& Development 43: 537-542.

Lambinet F. 1959. La glande mandibulaire du termite à cou jaune (Calotermes flavicollis). Insectes Soc. 6: 165-17.

Maddison WP, Maddison DR. 2010. Mesquite: a modular system for evolutionary analysis. 2011; Version 2.75. Available at: mesquiteproject.org/mesquite/download/download.html

Nakajima T. 1997. Cytochrome $\mathrm{P} 450$ isoforms and the metabolism of volatile hydrocarbons of low relative molecular mass. Journal of Occupational Health, 39: 83-91.

Noirot C, Quennedey A. 1974. Fine structure of insect epidermal glands. Annual Review of Entomology 19: 61-80.

Percy-Cunningham JE, MacDonald JA. 1987. Biology and ultrastructure of sex pheromone-producing glands. In
Prestchich GD, Blomquist GJ, eds. Pheromone biochemistry. London: Academic Press, 27-75.

Prestwich GD. 1984. Defense mechanisms of termites. Annual Review of Entomology 29: 201-232.

Quennedey A. 1984. Morphology and ultrastructure of termite defense glands. In Hermann HR, ed. Defensive mechanisms in social insects. New York: Praeger, 151-200.

Quennedey A, Sillam-Dussès D, Robert A, Bordereau C. 2008. The fine structural organization of sternal glands of pseudergates and workers in termites (Isoptera): a comparative survey. Arthropod Structure \& Development 37: 168-185.

Redford KH, Dorea JG. 1984. The nutritional value of invertebrates with emphasis on ants and termites as food for mammals. Journal of Zoology 203: 385-395.

Stuart AM, Satir P. 1968. Morphological and functional aspects of an insect epidermal gland. Journal of Cell Biology 36: 527-549.

Šobotník KJ, Weyda F, Hanus R. 2003. Ultrastructure of epidermal glands in neotenic reproductives of the termite Prorhinotermes simplex (Isoptera: Rhinotermitidae). Arthropod Structure \& Development 32: 201-208.

Šobotník J, Weyda F, Hanus R, Kyjaková P, Doubský J. 2004. Ultrastructure of the frontal gland in Prorhinotermes simplex (Isoptera: Rhinotermitidae) and quantity of the defensive substance. European Journal of Entomology 101, $153-163$.

Šobotník J, Weyda F, Hanus R. 2005. Ultrastructural study of tergal and posterior sternal glands in Prorhinotermes simplex (Isoptera: Rhinotermitidae). European Journal of Entomology 102: 81-88.

Šobotník J, Jirosová A, Hanus R. 2010a. Chemical warfare in termites. Journal of Insect Physiology 56: 1012-1021.

Šobotník J, Bourguignon T, Hanus R, Weyda F, Roisin Y. 2010b Structure and function of defensive glands in soldiers of Glossotermes oculatus (Isoptera: Serritermitidae). Biological Journal of the Linnean Society 99: 839-848.

Šobotník J, Bourguignon T, Hanus R, Demianová Z, Pytelková J, Mareš M, Foltynová P, Preisler J, Cvačka J, Krasulová J, Roisin Y. 2012. Explosive backpacks in old termite workers. Science 337: 436.

Šobotník J, Kutalová K, Vytisková B, Roisin Y, Bourguignon T. 2014. Age-dependent changes in ultrastructure of the defensive glands of Neocapritermes taracua workers (Isoptera, Termitidae). Arthropod Structure \& Development 43: 205-210.

Tillman JA, Seybold SJ, Jurenka RA, Blomquist GJ. 1999. Insect pheromones-an overview of biosynthesis and endocrine regulation. Insect Biochemistry and Molecular Biology 29: 481-514. 


\section{SUPPORTING INFORMATION}

Additional Supporting Information may be found in the online version of this article at the publisher's web-site:

Figure S1. Scanning electron micrograph of the mouth parts of Nasutitermes lujae, with antennae and part of the maxillary palp removed.

Figure S2. Labral gland development. Sagital sections of the labrum in: (1) Mastotermes darwiniensis, (2) Hodotermopsis sjoestedti, (3) Neotermes cubanus small soldier, (4) Neotermes cubanus large soldier, (5) Dolichorhinotermes longilabius small soldier, (6) Dolichorhinotermes longilabius large soldier, (7) Prorhinotermes simplex, (8) Psammotermes hybostoma small soldier, (9) Psammotermes hybostoma medium soldier, (10) Psammotermes hybostoma large soldier, (11) Termitogeton planus, (12) Glossotermes oculatus, (13) Reticulitermes flavipes, (14) Coptotermes formosanus, (15) Sphaerotermes sphaerothorax, (16) Pericapritermes sp., (17) Microcerotermes sp., (18) Spinitermes sp., (19) Globitermes globosus small soldier, (20) Globitermes globosus large soldier, (21) Globitermes sulphureus, (22) Termes hospes, (23) Inquilinitermes fur, (24) Neocapritermes taracua, (25) Planicapritermes planiceps, (26) Dentispicotermes brevicarinatus, (27) Labiotermes labralis, (28) Embiratermes neotenicus, (29) Indotermes sp., (30) Nasutitermes lujae, (31) Constrictotermes cavifrons, (32) Hirtitermes sp., (33) Trinervitermes sp.

Figure S3. Ultrastructure of the labral gland in soldiers. (A) Non-modified epithelium surrounding the labral gland in Hirtitermes sp. (B) Labral gland development in Hirtitermes sp. (C) Labral gland development in Nasutitermes lujae. Note the highly electron-dense vesicles. (D) Pinocytotic activity at the cell base in the labral epithelium in the large soldier of Dolichorhinotermes longilabius. Arrows indicate the pinocytotic activity at the base of the cell. (E) View of the central channel present in the microvilli, allowing secretion release from secretory cells. Abbreviations: en, endocuticle; ex, exocuticle; l, lipid-like droplet; mv, microvilli; n, nucleus; v, vesicle.

Figure S4 Ultrastructural features in the labral gland. (A) Highly modified cuticle underlying the labral gland in Neocapritermes taracua. (B) Detail of apical glandular cuticle at the tip of the labral gland in Nasutitermes lujae showing epicuticular pores allowing secretion out from the body. (C) Chemoreceptors containing four or five axons going through the labral epithelium in Hirtitermes sp. (D) Large microtubule bundles running through secretory cells in Hodotermopsis sjoestedti. (E) Tracheae going through labral gland cells in Mastotermes darwiniensis. Abbreviations: dd, distal dendrite; dg, electron-dense granule; en, endocuticle; ep, epicuticle; ex, exocuticle; lv, electron-lucent vesicle; $\mathrm{m}$, mitochondria; mb, microtubule bundle; mv, microvilli; $\mathrm{n}$, nucleus; s, secretion; ser, smooth endoplasmic reticulum; tr, trachea; v, vesicle.

Table S1. List of studied termite species, with indication of the fixation buffer used, collection location, species and subcastes (if any), number of repetitions, and labral and hypopharynx epithelium measures $(\mu \mathrm{m})$. The last four columns provide detail of the cells analysed by TEM, with indication of cell type, thickness of cuticular layers, smooth ER and presence of axons. Abbreviations: n.a., not applicable; Y, yes. 